\section{DISCUSSION AND CORRESPONDENCE HIGH TEMPERATURES AND EMISSION FROM GASES}

Is view of the discussion between Dr. A. S. King ${ }^{1}$ and Dr. G. A. Hemsalech ${ }^{2}$ upon the origin of the spectra obtained in the carbon tube furnace, it may be of interest to call attention to the complete absence of emission lines in mercury vapor, argon, nitrogen and hydrogen, when heated to $3200^{\circ} \mathrm{K}$. by means of a tungsten filament.

Observations of the heated zone adjacent to the filament while shielding the spectroscope slit from the filament radiation have shown no evidence of emission in the visible region from any of the above gases.

Professor F. A. Saunders was kind enough to photograph the spectrum from a tungsten spiral at $3200^{\circ} \mathrm{K}$. operating in mercury vapor at approximately atmospheric pressure in a quartz bulb. He obtained no trace of emission lines, but did find an absorption at $\lambda 2536$.

The potential gradient along the wires varied from about 1.5 volt per centimeter in mercury vapor to 15 volts $\mathrm{cm}$. in hydrogen.

These results suggest that the spectra obtained in the carbon tube furnace are neither primarily dependent upon potential gradient nor temperature, but are probably more of the nature of flame spectra produced by chemical reactions between the various elements present in the tube.

\section{G. M. J. Mackay}

\section{RESEARCH LABORATORY, General Electrio Co., SCHENECTADY, N. Y.}

\section{A POSSIBle RELATION BETWEEN MECHAN- ICAL, ELECTRICAL AND CHEMICAL QUANTITIES}

To The Editor of Science: In my note in your issue of November 26, page 509, on "A possible relation between mechanical, electrical and chemical quantities" (?), I regret that by an oversight I omitted to add that this relation applies to a valence of unity, as it is in the case of silver, which element was used in

1 Astrophys. Journal, 52, 187, October, 1920.

2 Phil. Mag., 36, 209, 281, 1920; 39, 241, 1920.' deducing it. For any other valence the atomic weight must of course be divided by that particular valence.

\section{Philladelphia, \\ December 2, 1920 \\ REQUEST FOR SEPARATES}

IN a note from Professor A. Dehorne, of the Institute de Zoologie, Université de Lille, France, it is stated that the straitened financial circumstances of the university library at Lille permit the purchase of but few biological publications, La Cellule, for example, being the only cytological journal received. In accordance with Professor Dehorne's request, may I urge cytologists and other workers in biology to send him separates of their published articles, and thus contribute to the development of biology at Lille. Such contributions can easily be made, and they will surely be appreciated very highly.

Lester W' SharP

\section{AN APPEAL FOR PUBLICATIONS FOR CZECHOSLOVAKIA}

Within the two brief years of its existence the new Czechoslovak Republic has established two new universities-one at Brno (Brünn) and the other at Bratislava (Pressburg), besides a series of high schools and several thousands of common schools. In addition, the University of Prague finds itself this year with a nearly redoubled number of students, of whom there are now over 10,000. With the generally and greatly reduced exchange value of European currency, it has become exceedingly difficult for the scientific men of these universities to provide themselves with literature published since 1914, and they appeal to their American colleagues for help in this direction. The publications needed are those reporting original research in all branches of science. Sets of reprints of individual investigators, and periodicals, will be particularly valued. Besides these, however, any reprints or scientifically valuable volumes that 
can be spared will be welcome, even though they may be of the older dates. The publications should be sent to the Czechoslovak Legation, 1732 N St. N.W., Washington, D. C., from where they will be forwarded to the men and institutions most in need of them through the International Exchange Bureau of the Smithsonian Institution; or they may be sent or delivered to the writer.

\section{A. HRDLǏ̌KKA}

U. S. National Museum, WASHINGTON, D. C.

\section{NOTES ON METEOROLOGY AND CLIMATOLOGY}

\section{HURRICANES}

We have been told by those who have visited the West Indies, that the natives have named the hurricane warning flag, which is displayed by the Weather Bureau, "el panuelo del Diablo," or the devil's handkerchief. Such a name conveys a fair impression of the natives' opinion of the hurricane. We are also told that the various hurricanes are named after saints of the church, and birthdates, marriage-dates, and death-dates, are reckoned from them. In other words, the hurricane is decidedly an event in the lives of those who experienced it. But the native West Indian is not the only one who has a respectful regard for the hurricane, for the vessel masters, whose ships ply the Gulf of Mexico, and those residents of the United States who inhabit the cities along the Gulf Coast have learned by sad experience to betake themselves to places of safety upon the approach of these interesting and destructive storms.

The West Indian hurricane, or tropical cyclone, is an area of low barometric pressure; but it differs in several respects from the extratropical Lows which cross the United States from west to east in unending procession. The isobars of the tropical cyclone are circular and the distribution of meteorological elements about the storm center is symmetrical, whereas the extratropical tow usually is elliptical in form and displays a marked lack of symmetry in the distribution of temperature, precipitation and cloudiness. The tropical storm which affects the West Indies and the United States, usually has its origin in the doldrums, or low-pressure calms which in mild-, and late-, summer lie along Tatitude about $10^{\circ} \mathrm{N}$., in the region of the Caribbean Sea and eastward. Its course is first toward the northwest, or west-northwest, and later, usually in about latitude $30^{\circ} \mathrm{N}$., curves northward and finally northeast. After entering the mainland the effect of the storm is soon lost; and, while it may be very destructive in the immediate vicinity of the coast, its further progress is characterized by a diminution of intensity and an acquisition of the characteristics of the extratropical Low.

One of the most troublesome features of the hurricane, from the meteorologist's point of view, is that the main part of its course lies over water, and, since ships make every effort to escape the storm, the forecaster is left in utter darkness as to the exact location of the disturbance and its direction of movement.' When a warning is once given of the presence of such a storm in the Gulf, all vessels in port refrain from sailing until the danger is passed. While this is decidedly profitable for the vessels, it makes the meteorologist the victim of his own efficiency, for it deprives him of observations of clouds, pressure, etc., which are so valuable to him in forecasting the part of the coast where the hurricane is most likely to strike. For this reason, it is necessary to utilize whatever observational data can be obtained along the coast, and Dr. Cline, of the New Orleans office of the Weather Bureau, has recently published a paper $^{1}$ in which he states his belief that the tides are a reliable criterion of the direction of motion of the hurricane while a considerable distance at sea.

Dr. Cline, after a brief mention of the wave-producing powers of winds, takes up all the hurricanes which occurred between 1900 and 1919: In their chronological order, he

1 Cline, Isaac M., "Relation of Changes in Storm Tides on the Coast of the Gulf of Mexico to the Center and Movement of Hurricanes,' Monthly Weather Review, March, 1920, pp. 127-146. 